\title{
Gendering the Border Effect: \\ The Double Impact of Colombian Insecurity and the Venezuelan Refugee Crisis
}

\begin{abstract}
:
In the Colombian-Venezuelan borderlands, the reconfiguration of armed group presence and mass migration create and reinforce conditions of high violence and risk. Against this backdrop, we ask: What are the gendered security implications of the double crisis in the borderlands? Based on fieldwork in four regions along the border, this article argues that the border effect is gendered; the very factors that coalesce to produce this effect exacerbate existing gendered power dynamics, particularly as these relate to gender-based violence. Accordingly, this article demonstrates the specific ways in which the border - as a facilitator, deterrent, magnet, and/or disguise - reinforces experiences of gendered insecurity in this region. The article finishes by outlining the implications for other international borderland settings.
\end{abstract}

\section{AUTHORS:}

1. Julia Zulver: Postdoctoral Gender Research Officer, Changing Character of War Centre, University of Oxford, United Kingdom. Correspondence: julia.zulver@pmb.ox.ac.uk Twitter: @JZulver

2. Annette Idler: Director of Studies, Changing Character of War Centre, University of Oxford, United Kingdom; Visiting Scholar, Weatherhead Center for International Affairs, Harvard University. Twitter: @ AnnetteIdler

\section{FUNDER INFORMATION:}

Funding for this research was made available by Global Affairs Canada as part of the CONPEACE (From Conflict Actors to Architects of Peace) Project, through the Changing Character of War Centre, Pembroke College.

\section{KEYWORDS:}

Colombia - Venezuela - border effect - borderlands - armed conflict - migration - sexual and gender-based violence

DISCLOSURE STATEMENT: The authors declare no conflicts of interest in the writing of this article. 


\section{Biographies}

1. Julia Zulver holds a Marie Skłodowska-Curie Global Fellowship (2020-2023), based at the IIJ, UNAM, Mexico and OSGA, Oxford, UK. In 2019 she was the Postdoctoral Gender Research Officer for the CONPEACE Programme at the CCW, Oxford. Her ongoing research focuses on women's grassroots mobilisation in high-risk settings in Latin America. This includes comparing women's high risk leadership in Mexico, El Salvador, and Colombia.

2. Annette Idler is the Director of Studies at the Changing Character of War Centre. She is also a Senior Research Fellow at Pembroke College, the Department of Politics and International Relations, and Affiliate at the Latin American Centre, all University of Oxford. During 2019/2020 she is a Visiting Scholar at the Weatherhead Center for International Affairs, Harvard University. Her research agenda lies at the interface of conflict, security, and transnational organized crime. Her work has been published by Oxford University Press and appeared in journals such as World Politics and the Global Journal for Security Studies. 


\section{INTRODUCTION}

"Gender violence will always exist, but it is amplified by conflict, socioeconomic issues, and migration." This statement from a Colombian government employee in Cúcuta (6 February 2019) illustrates the situation at the Colombia-Venezuela border in the late 2010s.

She made this remark during a period of heightened conflict. The demobilisation of the Revolutionary Armed Forces of Colombia-People's Army (FARC-EP) in 2016 after the signing of a peace deal with the Colombian government led to power vacuums that other violent nonstate groups, ${ }^{1}$ such as paramilitary successor groups, FARC dissidents, and criminal gangs continue to contest in their search for control over territory and illicit economies. The region also continues to face serious socioeconomic problems. In the context of weak state governance systems, along and across the border, communities lack basic services including electricity, health, education, road infrastructure to connect villages with towns and markets, and legal economic opportunities to sustain their livelihoods. Beyond this, the region faces unprecedented pressures caused by the influx of migrants and refugees from neighbouring Venezuela. The socio-political and economic crisis next door has led to almost five million people spilling across its borders into other countries in the region; almost 1.8 million of them settled in Colombia by early $2020 .^{2}$ Of those who settled, the majority inhabit Bogotá, followed by the departments of Norte de Santander and La Guajira - borderland areas where the humanitarian crisis worsened.

The reconfiguration of armed groups and the refugee and migrant crisis in combination create and reinforce insecurity in the border areas. The Venezuelans that arrive in these borderlands do not know the armed groups' "rules of the game". However, it is both borderlanders -Venezuelan and Colombian - and those who transit the borderlands that are exposed to precarious places. ${ }^{3}$ 
Both in contexts of armed conflict and in migration and refugee crises, insecurity affects some groups more strongly than others; women, in particular, feature among these vulnerable groups. ${ }^{4}$ The literature shows that women already face gendered vulnerabilities in their condition as migrants or refugees; ${ }^{5}$ the context of (gendered) violence in borderlands compounds the vulnerabilities to which they are exposed. Hence, in a setting where these two phenomena converge, we expect there to be a double burden for women. Against this backdrop, we ask: What are the gendered security implications of the double crisis in the borderlands?

To answer this question, we adopt a borderland lens that starts from the state's geographical and social margins: the border. The lens captures both conflict and refugee and migration dynamics, including the ways in which they feed into and reinforce each other to create a double impact of insecurity for borderlanders. This approach demonstrates that such border regions are exposed to a "border effect [that] consistently intensifies the logics of violent non-state group interactions, and with them, non-state order, making borderlands an extreme case of a complex security landscape". ${ }^{6}$ It can take shape in four mechanisms: border as facilitator, border as deterrent, border as magnet, and border as disguise. ${ }^{7}$

We argue that the border effect is gendered; the very factors that coalesce to produce this effect exacerbate existing gendered power dynamics, particularly as these relate to gender-based violence. The double crisis in the Colombian-Venezuelan borderlands makes the border effect particularly discernible: it increases the insecurities and vulnerabilities of those exposed to it. ${ }^{8}$ It also intensifies this gendered character of the border effect; the distinct insecurities women experience in the context of the double crisis in the borderlands are particularly severe because the border effect facilitates sexual and gender-based violence (SGBV), makes women - 
including those migrants and refugees who pass through or newly inhabit borderland spaces vulnerable to prostitution and sexual exploitation, and hinders access to support systems.

Existing theories fall short in explaining the distinct experiences of insecurity that women face in borderlands when exposed to the double impact of armed conflict and a refugee and migrant crisis. The conflict studies literature, for example, shows that women experience armed conflict in a way that is distinct from their male counterparts. ${ }^{9}$ Accordingly, Cockburn stresses that concepts of security must incorporate women's differential experiences to secure lasting peace. ${ }^{10}$ Boesten and Wilding add that "violence against women may take different forms and be of a different scale during periods of conflict." 11 They argue that post-conflict settings are often unable to address the messier agendas presented by women's multiple experiences, identities, and voices.

In the case of the Colombian armed conflict, scholars have shown how women have been affected in multiple and intersecting ways. ${ }^{12}$ They do not problematise, however, situations in which foreign nationals arrive in contested territories, where it is hard for them to meet their basic needs, and where they lack social networks and an understanding of the local conflict dynamics.

Refugee studies tend to highlight the capacities of women in their identity as vulnerable actors. ${ }^{13}$ Such scholarship, for instance, demonstrates female refugees' agency in establishing new livelihoods in the place where they settle. Rather than being passive victims, women for example actively seek job opportunities, often as single heads of household. This literature also reveals the difficulties women face due to gender-based discrimination and cultural norms, even when they arrive in a supposedly safe environment. ${ }^{14}$ These dynamics hinder their social, economic, and political integration in the host country. 
The body of literature on human trafficking adds further insights, especially on those elements of gendered violence that concern women "on the move". For example, Freedman's research with Syrian, Afghani, Eritrean, and Iraqi women in the EU highlighted the multiple forms of SGBV they faced at home, on their journeys, and upon arrival, including at the hands of smugglers, border guards and coastguards, and even other refugees. ${ }^{15}$ Other work shows similar patterns of violence for women from Sub-Saharan Africa who are attempting to migrate to Europe ${ }^{16}$ and for Central American and Mexican migrants attempting to get to the United States. $^{17}$

Finally, borderland studies theorised the role of borderlands for armed conflict and violence, ${ }^{18}$ and also recognised the gendered role of borderlands. ${ }^{19}$ However, this work does not address the double impact women suffer in contexts of migration and conflict crises, despite the frequent nature of such scenarios.

Our theoretical and empirical contributions lie in our analysis of women's experiences of multiple insecurities along the shared border of two states in crisis - admittedly different types of crises - as a function of the nature of borderlands themselves, rather than as a clear-cut combination of either the refugee and migrant crisis or the reconfiguration of a conflict zone. By linking borderland studies, conflict studies, refugee studies, and the human trafficking literature with gender studies, we move beyond solely looking at migrants, refugees, and borderlanders and the specific risks they face. Instead, we account for the unique characteristics of the zones or territories in which they move and live as spaces that are particularly dangerous for women because of their reinforcement of insecurity in the context of conflict and mass migration.

While our research offers a nuanced picture of how the border can act to create sites of risk for women, it does not mean to represent women as lacking agency or necessarily in need of 
protection. ${ }^{20}$ Indeed, scholars are quick to highlight that focusing on (or even fetishising) sexual violence can lead to a masculinist and securitising response to women's experiences. ${ }^{21}$ Such a response does not offer insight into the multiple and gendered coping strategies that migrants and refugees (including men) adopt during forced migration. ${ }^{22}$ We do not wish to perpetuate this pattern. Indeed, other scholars point to women's mobilisational agency and empowerment that develops as a function of their experiences with violence ${ }^{23}$, or after an experience of intense conflict or atrocity. ${ }^{24}$ Instead, we reveal these patterns to provide a basis for further debates on women's experiences and agency in such contexts.

We derive the evidence of this study from qualitative research that includes semistructured interviews with borderland dwellers between January and May 2019. It focuses on Venezuelan, Colombian, and retornado ${ }^{25}$ populations who inhabit these territories. Field sites are located in the Colombian border zone that adjoins neighbouring Venezuela. They are part of the Colombian-Venezuelan borderlands affected by the border effect.

Fieldwork took place in four sites: (1) Cúcuta (metropolitan area and Villa Rosario), (2) Catatumbo (Tibú and Sardinata), (3) Arauca (capital), and (4) La Guajira (Riohacha, Maicao, and Paraguachón). We selected these cases because of their representativeness of distinct parts of the Colombian-Venezuelan borderlands and different types of non-state order. They allow for insight into rural and urban settings in areas that all feature the presence of violent non-state groups and an influx of migrants and refugees fleeing Venezuela's humanitarian crisis. They represent "most similar settings"26, allowing us gain insight into the border effect. Despite this, given distinct socio-political and cultural contexts, racial and ethnic makeup, geographical features, and control by different conformations of armed groups, ${ }^{27}$ research in these sites further 
allows for a diversity of observations that facilitates insight into the differences between borderland communities.

We draw on 149 anonymous interviews in Spanish in individual and group settings, including five types of actors: Colombian retornados (25), Venezuelan migrants and refugees (34), members of Colombian civil society organisations $(54),{ }^{28}$ representatives of international NGOs or think tanks (IHO, 7), United Nations agencies or contractors (12), and representatives of Colombian institutions (17). Of these, 26 interviewees were men and 123 were women (cis and trans). Interview data were complemented with participant observation in community meetings, neighbourhoods, parks, red-light districts, formal and informal border crossings, and shelters to gain a deeper understanding into the social situation.

After unpacking the theoretical value of adopting a borderland lens to studying insecurity, we outline the contemporary context of the Colombia-Venezuela border (until May 2019) and demonstrate how the four mechanisms of the border effect contribute to the gendered experiences of insecurity in these borderlands. We conclude by discussing the relevance of our findings for other borderland regions internationally, and outlining policy implications as well as avenues for future research that emerge from our work.

\section{THE BORDER EFFECT}

Borderlands are territories that straddle both sides of an international borderline. They are constantly in flux; their width is determined by the extent to which interactions near and across the borderline influence dynamics in this territory. Borderlands are unique spaces in that they are characterised by their distance from the state centres and their transnationality - they are traversed by an international borderline. 
There is a growing border studies literature that examines how bordering practices negatively influence the security of those at whom these practices are aimed. ${ }^{29}$ In particular, bordering practices at international borders harm those trying to cross. ${ }^{30}$ Cassidy, Yuval-Davis, and Wemyss highlight that such bordering is intersectional; it is not simply a question of "who moves and who does not but also about who is in a position of control in relation to movement." 31 In this sense, the concept of bordering helps understand how this process of differentiating between "us" and "them" produces bordering effects, e.g. by contributing to the stigmatisation of (female) migrants and refugees arriving in another country, therefore increasing their vulnerabilities. It does not, however, provide analytical leverage to understand the effect of the geography of borderlands - dissected by an international borderline - on everyday lives in these spaces, both the lives of those on the move and of those who remain permanently.

We therefore follow Idler by adopting a transnational borderland lens and engaging with her theorisation of the border effect to examine the gendered security implications of the double crisis in the borderlands. ${ }^{32}$ Rather than only focusing on the border and related practices, this approach facilitates a direct focus on the challenges of (mass) migration in the context of an armed conflict; these challenges are interlinked with the geography of borderland spaces, which lies at the core of the border effect.

In contexts where the state's capacities do not fully reach its peripheries, and where neighbouring countries have not adequately coordinated their respective economic, justice, and security systems, the universal characteristics of transnationality and distance from state centres translate into weak state governance, a proneness for impunity, and high incentives for engaging in illicit cross-border activities. Together, these factors create a "border effect" that intensifies 
people-centered insecurities while obscuring them from those outside the borderlands in four ways: as a facilitator, a deterrent, a magnet, and a disguise. ${ }^{33}$

As a result of the borderlands' transnationality, the border acts as (i) a facilitator and (ii) a deterrent. The border is a "facilitator" for violent crime, due to its 'filter mechanism.' Beyond landscapes, history, and everyday life that are shared by both sides of the border, ${ }^{34}$ non-state actors also spill across borders, while law enforcement agents are constrained by national sovereignty ${ }^{35}$, increasing the vulnerability of local communities to abuse. It is a 'deterrent' because the transnationality of borderlands deters violent non-state groups from trusting their counterparts on the other side of the border. Such heightened inter-group mistrust also makes them suspicious of borderlanders and their allegiances. This fuels interpersonal mistrust.

Due to the distance from the centre, the border is (iii) a magnet and (iv) a disguise. It is a 'magnet' for those involved in illicit businesses, given the profits that can be made through illicit cross-border activities in the context of weak state presence and hence a relatively low likelihood of being prosecuted for these illegal activities. The high prevalence of illicit economies and presence of multiple actors involved in them impacts people's local livelihoods and economic opportunities. Additionally, it can act to 'disguise' nuanced forms of violence. State-centric views stigmatise borderlands as generally violent spaces $;{ }^{36}$ borderlands are seen as unruly and dangerous spaces, without acknowledgement of the many nuances in which insecurity might take shape and the distinct ways in which different groups - including women - are affected by them. ${ }^{37}$

The transnational borderland lens adopted in our research facilitates investigating how the geography and political economy of borderlands produces distinct forms of gendered insecurities in the context of ongoing conflict- and crime-related violence in Colombia, and the 
additional pressure resulting from the humanitarian repercussions triggered by the Venezuelan social, political, and economic crisis.

In multi-party conflicts in which both armed conflict and organised crime converge, as in Colombia, reconfiguration of armed actors - not their disappearance - characterise transition periods that follow a peace deal with one rebel group. Still active rebel, paramilitary, and criminal groups (as well as dissidents of the demobilised group) aim to fill the power voids of the demobilised group, especially if this group not only aimed to overthrow the central government, but also had considerable stakes in the illicit economy. The border effect is a useful 'ally' to achieve this goal.

When this re-ordering of armed groups takes place in the context of a massive influx of migrants and refugees from the neighbouring country suffering a crisis, the border effect exacerbates additional risks. First, not only borderland communities, but also arriving migrants and refugees are exposed to the heightened insecurities that result from the activities of the armed actors - that is, the sheer number of people suffering in this context increases. Secondly, these people are particularly vulnerable, as they often arrive without documents, access to services, or a clear understanding of how to navigate a situation of ongoing armed conflict.

A gender lens that analyses power dynamics in the context of the double crisis highlights that women and girls (both cis and trans) are exposed to insecurities resulting from the border effect in a distinct, and particularly severe way. The risks to them are different from their male counterparts. In the Latin American context of machismo, women face SGBV, including sexual abuse, often in a context of normalisation of this violence. ${ }^{38}$ Girls and women are more prone to becoming victims of human trafficking and more likely to engage in prostitution, including survival sex. ${ }^{39}$ Just as these dynamics are obscured under the disguise of general "danger" in 
borderlands, these specific and gendered insecurities also remain hidden, making women vulnerable to an exacerbation of the situation without any action being taken to alleviate the suffering.

\section{HOW THE GENDERED BORDER EFFECT PLAYS OUT IN THE COLOMBIAN-VENEZUELAN BORDERLANDS}

Colombia's borderlands have been exposed to armed conflict for decades. The areas that adjoin the 2,200km long borderline that both separates and unites Colombia and Venezuela have been some of the country's most conflict-affected regions. Within the borderlands, however, there are inter-regional differences. For example, the department of Arauca in the south faced a brutal war between the ELN and FARC guerrilla groups in the 2000s. This guerrilla war ended in 2010, but armed activities against the state, and especially the oil industry continue; in 2020 it remains a major ELN strong hold. Further north, in Norte de Santander, multiple groups including the FARC, ELN, EPL, and paramilitary groups both cooperate in and fight for control of strategic corridors used in the cocaine business. The Catatumbo region in particular - a site of coca cultivation, cocaine production, and transit zones - has historically hosted armed actors, while state presence is mostly limited to military installations. Further north, in Cesar and in La Guajira, the trafficking dynamics likewise converge with conflict dynamics, complicated by the presence of the indigenous Wayúu, a binational population inhabiting the Guajira Peninsula on both sides of the border.

The social, political, and economic dynamics in this border zone cannot be understood without also considering the Venezuelan side of the border. Since long before the crisis (that intensified in Venezuela after former president Chávez' death in 2014), family and commercial 
links have extended across the border; and armed groups have operated across the borderline as well. The more recent situation complexifies matters even further: Colombian refugees in Venezuela decided to return to their home country (retornados); Venezuelans left their country in the hope for better opportunities in Colombia and elsewhere, and armed groups extended their presence both ways, taking advantage of the messy situation.

This context is not static. Even during fieldwork, the security landscape was constantly changing, particularly related to border closures and the subsequent required use of informal trails across the borders. Against this backdrop, in the remainder of this section we demonstrate how the border effect heightened gendered insecurities in the Colombian border zone affected by this double crisis.

\subsection{Border as Facilitator}

When the border acts as a facilitator, it facilitates the concealment of victimisation, promotes illegal economies, and obscures social control by violent non-state groups, allowing for illicit cross-border authority. This plays out in multiple gendered ways across the Colombia-Venezuela border, particularly in its manifestations as gendered violence in informal border crossings and human trafficking.

Insufficient cooperation between law enforcement authorities across the border, and deficient state presence, gives rise to impunity. This situation brings particularly severe risks for women: when crossing the border at informal trails, they find themselves at the mercy of violent non-state groups.

In addition to official border crossings between Venezuela and Colombia, the border is crisscrossed with informal ones. ${ }^{40}$ While local communities use them to visit family members, 
take their children to school, and engage in small-scale (illicit) cross-border trade of household goods, conflict and criminal actors do so to cross the border out of the sight of authorities. During the closure of the official border posts (which took place during field research), these crossings - some parallel to the official ones - were the only way for migrants, refugees, and border-dwellers to cross between the two countries. They became the object of competition for territorial control between both Colombian and Venezuelan violent non-state groups who charged tolls to anyone who wanted to transit the passage.

Interviewees recounted experiences of passing through informal trails on foot near the Simón Bolívar bridge in Cúcuta and through the desert crossings in Paraguachón in La Guajira, as well as via canoe in Arauca. In the Catatumbo region, where no official crossings exist, people use terrestrial and fluvial informal passages. While these had been in use for a long time, they became the only way to move between Colombia and Venezuela during border closures.

In Paraguachón, for example, women who passed through La Cortica or La Ochenta (the two major informal crossings) were required to pay those who control the passage. Interviewees described how women who traversed were sometimes subject to sexual violence if they or someone in their group did not have sufficient resources to pay the toll. This sexual violence ranged from touching, to forced sexual acts, to rape, which often took place publicly.

At the informal crossings next to the Simón Bolívar Bridge in Cúcuta, women were also vulnerable. The local head of an international humanitarian organisation confirmed:

We know that when [women] cross, especially those who are undocumented and are moving in an irregular fashion, are subject to harassment, extortion, rape, and transactional sex when they cross the border...that's a huge issue because basically all of the border crossings are controlled by armed groups and criminal gangs (Interview, 5 February 2019). 
A UN employee in Cúcuta further described another element of the specifically gendered repercussions of violence in the informal crossings:

The situation is getting worse... the worst cases are for those who enter through informal border crossings, I have heard thousands of stories. There is sexual abuse, and many of these cases end up in pregnancies...but because of the dynamics in Venezuela they don't denounce to anyone because they're afraid (Interview, 7 February 2019).

Incidents of gendered violence facilitated by the border are not confined to border crossings, they concern women on the move more broadly, especially in the form of human trafficking. The literature around human trafficking highlights the gendered vulnerabilities people face when they occupy, are fleeing from, and are transiting through conflict-affected areas, including in borderlands like Myanmar-China and Eritrea-Sudan. ${ }^{41}$ Similarly to these cases, there are particularly gendered implications of human trafficking in the context of the VenezuelaColombian border. The border effect facilitates human trafficking due to the way it renders this crime invisible and conceals the violence associated with it.

Venezuelan migrants and refugees are prime targets for violent non-state groups who either run or support trafficking networks. Data about trafficking are almost completely lacking (as will be discussed below); a government employee in Cúcuta revealed: "there are two cases of human trafficking that have crossed my desk, but I think this is the just the tip of the iceberg" (Interview, 6 February 2019). She referred to multiple stories whereby Venezuelan women came to Colombia to work as domestic staff and end up without documents and without being allowed to leave the house.

A UN employee discussed the involvement of violent non-state groups who recruit women - often those who do not understand the local dynamics of conflict - to go and work on a 
farm. The women are forced to cook, clean, harvest coca, and meet combatants' sexual needs; "we don't know anything about these women, who they are, where they are. We know that there is human trafficking and that there are many clandestine locations in Catatumbo where they are exploited sexually" (Interview, 8 February 2019).

Many interviewees referred to Arauca as a particularly dangerous place for women in terms of trafficking. According to an employee of a women's centre in the city the phenomenon was worsening: "Arauca is used as a corridor for migrants and refugees to get to bigger cities, there is no control. It is a very easy corridor to move things. If they are minors, children, you can takeout whatever you like" (Interview, 29 March 2019). Another civil society representative explained: "you hear a lot about the trafficking of young girls. Arauca is a small and isolated city - we have a river and you can cross anything you like" (ibid.).

In the absence of accessible official statistics on trafficking, a UN employee explained the mechanics of the trafficking business that increased in the context of the Venezuelan crisis:

There are groups waiting to prey on girls when they arrive at the transportation terminal. For example, ten girls disappeared from the terminal last year. It is hard to identify these cases. The groups might not be running the networks, but they approve of it because they control everything [here]. The [state] institutions don't respond to what is going on. No one activates the routes. There is a committee about this, but nothing ever happens. The government institutions pawn it off on the humanitarian organisations (Interview, 29 March 2019).

Three other interviewees independently confirmed these mechanics and the lack of state response, suggesting that it had become a little visible, but worrying pattern along the borderline. It is not only women on the move, but also those settled in borderland spaces who experience the double impact of both the conflict's insecurities and the refugee and migrant crisis. Adopting the 
borderland lens sheds light on how the gendered border effect negatively influences the security of these individuals, even in borderland spaces that are not directly situated at the borderline.

\subsection{Border as Deterrent}

When the border acts as a deterrent, it reduces predictability, increases exposure to selective violence, fuels distrust between violent non-state groups, and intensifies interpersonal distrust. When it comes to women's experiences of insecurity, this is most clearly manifested in two phenomena: xenophobia and prostitution.

Interviewees all along the border considered Venezuelan migrants and refugees engaging in prostitution a new problem. ${ }^{42}$ In borderlands, prostitution is related to xenophobia in two ways: (1) given the lack of trust relationships and discrimination against female migrants more broadly, ${ }^{43}$ migrant women were unable to find an income source and hence felt they must resort to prostitution, and (2) Venezuelan women were assumed to be prostitutes, often just because of their accents, and were treated with varying degrees of violence as a result. Moreover, in order to earn more money, some women sold sex in dangerous settings controlled by violent non-state groups (as discussed in below sections).

Of twelve Venezuelan prostitutes who participated in a group interview in a brothel in Cúcuta's red light district, none had previously been a sex worker. Among them was a waitress, a radiographer, a security guard, and a lab technician. One woman related that she had tried to sell ice cream when she arrived in Colombia, but when her son got a lung infection, she needed to earn more money quickly, and the only job a female migrant could perform to earn sufficiently was selling her body for sex (Interview, 8 March 2019). Another woman began to work as a prostitute to send money to Venezuela to buy food for her children since, having 
travelled without passport, she was not legally allowed to work in Colombia and could not find any other job. Similar stories abounded: "many of [us] arrive without documents...so we end up in this role, sex work" (Interview, 5 February 2019).

The xenophobic attitudes extended beyond prostitutes. As an international organisation representative explained:

The first thing that Venezuelan women are offered is sex work. The first thing they are offered, but not the first thing they choose. We have many cases of women who say, I tried [many things], but I had to accept that I was going to be a prostitute. Many women are involved in informal work, at the traffic lights [selling] lollipops or phone chargers... And [they face] stigma and discrimination, constant sexual harassment... in the street, in the business areas. If a Venezuelan girl is a waitress, there's an assumption that she's a prostitute as well.” (Interview, 6 February 2019).

A Venezuelan woman living in an informal settlement near the Cúcuta airport complained: "I sell coffee, I don't sell my body!" (Interview, 7 March 2019). She referred to a trait related by many interviewees across field sites: the image of the Venezuelan migrant who sells coffee out of a thermos as a way to identify a prostitute. For example, asking a woman how much it would cost for "the entire thermos" is a euphemistic way of asking how much she charges for sex.

Certainly, Colombian women working as prostitutes are also exposed to abuse, yet the additional factor of being a Venezuelan woman from across the border - in a context of xenophobia and distrust - increases their vulnerability when arriving in the Colombian border zone. Although technically any SGBV that women of any nationality face on Colombian soil is illegal under Law 1257 (2008), Venezuelan women without regular migration status fear that approaching the authorities will lead to deportation. Prostitutes and NGO workers interviewed 
mentioned that Colombian migration authorities and the police had actually been perpetrators of violence against them.

\subsection{Border as Magnet}

Border zones are close to borderlines, and thus attract multiple violent non-state groups due to the high opportunity-low risk environments. This boosts profits, reduces civility and respect, thwarts government countermeasures, and consolidates consent to illicit authority. ${ }^{44}$ Examining this dynamic with a gender lens reveals that women are primarily affected given two phenomena: (1) the coalescence of armed groups, illegal economies, and sexual exploitation, (2) ongoing territorial contestation and control.

As examples such as the coca industry in Catatumbo or the contraband and trafficking industries in Arauca and La Guajira demonstrate, border areas offer huge profits in illicit economies. Border-dwellers, both Colombians and Venezuelan migrants and refugees, with few other options join these industries; in the case of Catatumbo this manifests as raspachines, coca leaf harvesters. ${ }^{45}$ Secondary industries spring up around coca-growing and harvesting. Many rural workers spend their weekends drinking at local bars and paying for sex with prostitutes. In the rebel camps, women are often brought in as cooks and cleaners, and are forced to meet the militants' sexual needs.

Beyond the presence of violent non-state groups, it is also the change of who is charge affects women exposed to these dynamics, particularly since the FARC's demobilisation. Catatumbo represents a dangerous location for women involved in prostitution. The region is divided between violent non-state groups who, at the time of fieldwork, engaged in violent combat to (re-)gain parts of the region. Only days before fieldwork was conducted, FARC 
dissidents had entered the municipal centre of Tibú to destroy a series of security cameras installed by the municipality and fought the Colombian army. An interviewee from a dangerous neighbourhood on the outskirts of Tibú recalled increased incidences of feminicide in the area, mainly against prostitutes in the bars frequented by armed groups - "it is a slaughterhouse!" (Interview, 4 April 2019). Another interviewee, herself the survivor of sexual violence at the hands of the paramilitaries and the Venezuelan Guard, related:

Venezuelan women have a hard time - they [armed groups] are killing them... [there is] sexual and labour exploitation... some of them have been tricked into groups, they kill them in the billiards halls, [there is] social cleansing (4 April 2019).

The varying degree to which different groups permit prostitution complicates the situation. In Sardinata, for example, armed groups allow sex work two bars while in other places they prohibit it. An interviewee reminisced about how "when there was FARC control, there was respect, but now there are disputes [between the ELN, EPL, and FARC dissidents]" (Interview, 2 April 2019). Data points on feminicide in these contexts are difficult to confirm with official statistics; ${ }^{46}$ as we will discuss below, gender-sensitive data collection mechanisms could shed more light on the nuances of this phenomenon.

When territorial control is constantly shifting due to competition over illicit cross-border economies, so too do the rules of social behavior. Particularly for those who do not know how to navigate armed conflict contexts - i.e. Venezuelan migrants and refugees - this can have deadly repercussions. An OCHA report expresses worry that the enforced clandestine nature of prostitution results in difficult verifying that the rights and health of sex workers are respected. It also states that the situation may give rise to sexual and human trafficking networks. ${ }^{47} \mathrm{~A}$ UN employee who works in Catatumbo confirmed: 
It is very difficult to know who is entering, if they get recruited or are disappeared and taken to farms, we don't know how many are there... we don't know anything about these women, who they are, where there are. We know that there is human trafficking and many clandestine locations in Catatumbo where they are sexually exploited.... the armed groups begin to control women's bodies. The groups have social, political, economic control. (Interview, 8 February 2019).

Field research in La Guajira and Arauca provides multiple examples that confirm this dynamic in these parts of the country as well. ${ }^{48}$

The double problem of the humanitarian crisis and the heightened presence of violent non-state groups can create insecurity for vulnerable women, particularly those engaging in survival sex, many of whom are Venezuelan or retornadas. The risks around sex work Venezuelan migrants in the borderland territories face differ depending on the violent non-state group in control. Assessing these risks, however, is difficult, given the change in who is in control. Moreover, Venezuelan migrants and refugees do not have experience living in contested territory and do not know "the rules of the game."

One interviewee stated a paramilitary soldier raped her at gunpoint while she was working at a bar in a village in rural Catatumbo. The village, a long-time hotbed for illegal economies - did not allow the state (i.e. the army) to enter, and violent non-state groups were required to follow a local set of "Coexistence Guidelines". ${ }^{49}$ When she reported the rape, the local authorities did not take steps to guarantee her ongoing safety. At the time of fieldwork, she lived in Cúcuta, and frequently received threats from her attacker.

While local authorities try to mitigate the violence of clashing violent non-state groups, this can lead to situations whereby women - particularly those engaging in (or assumed to be engaging in) prostitution - are not able to enjoy safety given the complex dynamics that result from the presence of multiple armed groups. Ensuring a pacific dynamic between the various 
groups and the town therefore eclipses women's - including an influx of Venezuelan women'sspecific safety needs. In Arauca, an interviewee reported: "there are very few denouncements here because of fear of the groups" (Interview, 29 March 2019). This is a common narrative repeated throughout the borderlands. For example, in Sardinata, a town in Catatumbo, an interviewee reported "the [armed] groups are using GBV - rape - but they threaten [you] with murder if you denounce them, and they follow through with their threats" (Interview, 2 April 2019). This creates a situation of rule of silence whereby citizens do not report acts of violence. ${ }^{50}$ They are afraid of violent retribution, one of the main barriers to justice for borderlanders, particularly women who are already rendered vulnerable by the ubiquity of survival sex and machista power dynamics that silence them.

\subsection{Border as Disguise}

Given borderlands' distance from power centres, they are considered as stigmatised spaces, alienating the communities who live there from the state. When the border acts as a disguise, it impacts women insofar as it translates into (1) a lack of access to justice, and (2) a lack of nuanced data and data collection mechanisms.

Along the border, access to justice systems, for both migrants and Colombians, was lacking. Again, while this is the case for men as well, it has gendered dimensions when it comes to women's experiences of insecurity. For example, multiple sources noted that if a woman is a victim of abuse at an informal border crossing, she cannot report it because the abuse did not take place in Colombian territory. Furthermore, migrants and refugees do not know their rights as foreigners on Colombian soil. A Colombian government employee confirmed: 
[Venezuelans] don't know how to access justice institutions, they have barriers to access because public functionaries sometimes don't receive their complaints because they're Venezuelan. The Law 1257 is for all women who are in the national territory" (Interview, 6 February 2019).

A double dynamic is illustrated here: (1) women do not know their rights and do not know how to access justice, and (2) even when migrant women do report crimes, Colombian institutions do not register or accept their denunciation. A worker of an international humanitarian organisation elaborated:

Venezuelan women go to the police, but they are told that they won't receive their denunciations. And this isn't true, but it shapes their relationships with [state] institutions. If you go to the institutions and are rejected or blamed for what happened, you stop going to the institutions (Interview, 4 March 2019).

Added to this dynamic is a culture of fear around deportation or ongoing violence at the hands of armed groups. In Arauca, the head of an NGO expressed:

The girls don't know the laws. They don’t know their rights. They think that as children they're going to be taken away and locked up by [family services], or if they're Venezuelan they think they're going to get in trouble with Migración, so they don’t look for help. (Interview, 29 March 2019).

NGO workers in Tibú corroborated: "In the rural areas... women don’t denounce because they're afraid, and because of cultural machismo" (Interview, 4 April 2019). The same was the case in La Guajira: “there isn't anything going on at the border regarding GBV.... There aren't any answers here for women. They are afraid to denounce because they think they'll be deported" (Interview with UN official, 10 April 2019).

Deficient state capacity also prevents women's access to justice. In Arauca, for example, a safe space for Venezuelan women arriving in Colombia was only opened in March 2019. A UN employee noted: 
Institutions don't respond to what is going on. No one activates the route here. There is a committee, but nothing ever happens. The government institutions pass it off on the humanitarian organisations and rely on them" (Interview, 29 March 2019).

Although this attention centre represents an opportunity for women to access services, its limited capacity meant that many cases did not receive due attention.

One of the biggest challenges to understanding gendered insecurities in the borderlands is the lack of data related to SGBV along the border. As Goetz reminds us, particularly in the case of gendered violence: "it is a truism among monitoring and evaluation specialists that what doesn't get counted doesn't count." ${ }^{, 51}$ Beyond this, in a border context, armed actors take advantage of this invisibility of SGBV dynamics. As a government worker in Cúcuta stated: "the women are afraid; they are invisible. The perpetrators take advantage of the fact that they are almost invisible" (Interview, 6 February 2019).

Data on SGBV are lacking in many parts of the country yet it is heightened in borderlands due to the deficient capacities of governmental and international organisations in the context of the double crisis (Interviews with UN employee in Riohacha, government employee in Maicao, international organisation staff member in Cúcuta, and others). The closure of the Simón Bolívar bridge that led to all passage from Venezuela to Colombia having to take place through informal channels further limited the ability to collect data. When paired with the lack of access to justice and the fear and rumours that Venezuelans hold regarding their ability to denounce crimes, the situation further muddies. A gender specialist at an international organisation in Bogotá said: "[regarding trafficking networks], there is no way to document is. Venezuelans don't denounce. No one else denounces. But everyone knows it's happening” (Interview, 21 February 2019). 
In concert, this leads to a situation where authorities do not know how to either effectively measure SGBV or activate the necessary routes to provide support. An interviewee in Arauca was clear: "We are in the peripheries and we are completely invisible, even though we are governed from Bogotá" (Interview, 29 March 2019). When the border acts as a disguise, there is an assumption in the power centres that borders are dangerous without looking at the disaggregated risks this means in reality. For both Colombian and Venezuelan women who navigate a complex security environment, this has severe repercussions. So long as SGBV is 'not counted', it remains invisible and thus is not included in humanitarian and government programming.

\section{CONCLUSIONS}

In the Colombian-Venezuelan borderlands, "conflict" did not end with the signing of the 2016 Peace Accords. Moreover, violence - particularly as it manifests as SGBV - in this territory cannot be attributed solely to the reconfiguration of the security landscape as new and existing violent non-state groups vie for territory and access to illegal economies. Indeed, at the time of writing, almost 1.8 million migrants and refugees have crossed the borderline - and for now remain - in Colombian territory. Many arrive without employment opportunities or social networks, and, notably, without the long-standing knowledge of the "rules of the game" when it comes to armed conflict shared by their Colombian neighbours. Women - Colombian, Venezuelan, and retornadas - who navigate these complicated borderland spaces, are at risk of heightened SGBV. This risk becomes clearest when a borderland lens is adopted, which takes the transnationality and distance from the centres of power (Caracas and Bogotá) of these borderlands as a starting point for analysis. 
Accordingly, this article demonstrates the specific ways in which the border - as a facilitator, deterrent, magnet, and/or disguise - reinforces experiences of gendered insecurity in this region. It increases women's susceptibility to SGBV in the context of both Venezuela's humanitarian crisis and the reconfiguration of armed group presence in Colombia's changing security landscape.

This finding is relevant for border areas across the world. Today, many settings of violence and fragility spill across state border and migrants and refugees frequently arrive in unknown, violent contexts, rather than safe havens. Indeed, the world's most lethal crises today comprise transnational, rather than national dynamics of violence and illicit economies and thus affect individuals and communities even after crossing the border. Regions including the Middle East and North Africa, South Asia, and the Horn of Africa feature borderlands affected by both an influx of refugees or other migrants and ongoing national conflicts. In such settings, desperate for income, food, and shelter, and unfamiliar with how to access (often limited) state resources, women migrants and refugees in particular are at risk for violence - including recruitment, trafficking, and inclusion in illegal economies - by violent non-state groups. Consider for example female migrants crossing from Somalia into Kenya, from Libya into Tunisia, from Syria into Iraq, or from Afghanistan into Pakistan, to name just a few examples. Such contexts feature additional complexities for example to ethnicity and religion, that are largely absent in the Colombian-Venezuelan context. Our study suggests that in such cases the border effect likewise reinforces gendered insecurities. Further research with a borderland approach and a gender lens that considers the unique characteristics of these cases would be necessary to scrutinize whether the four border effect mechanisms play out in a similar way. This will further add to feminist understandings of armed conflict, which do not always draw deeply from borderland scholarship. 
Indeed, by gendering the border effect, we are able to expand beyond a peace/conflict binary to understand the nuanced ways in which women inhabiting borderland spaces are exposed to SGBV as a function of the interaction between conflict and refugee and migration dynamics. Moreover, beyond refugee literature that examines women's experiences in their home countries, on the move, and in receptor countries, this article helps understand the particularities of what it means to inhabit or pass through a borderland itself.

Certainly, women in such contexts are not solely vulnerable victims. Accordingly, framing the border effect as gendered opens up the opportunity to further discuss the grounded realities of women's experiences in a double crisis. Such a task is important for understanding conflict, and responding in a holistic, feminist fashion.

The research presented in this article therefore has important policy implications. With the border effect being gendered, humanitarian programming and security policies need to take differential approaches to the way that they both identify, categorise, understand, and react to SGBV in border regions. Moreover, it also opens a discussion about how to best support programmes that bolster women's agency in these complex security settings. Perhaps most importantly, this begins by finding ways to appropriately collect data in a nuanced fashion, a feat that is anything but simple in a context where survivors of violence are often reluctant to report, and access to justice institutions is scarce and underfunded at best, and absent at worst. By unpacking the various ways in which the border effect has distinct repercussions on the security of women, and thus highlighting its gendered nature, we hope this article makes a first step toward this direction. 


\section{REFERENCES:}

Achtnicht, Marthe. "Mobility in Crisis: Sub-Saharan Migrants' Journeys through Libya and Malta [Doctoral Thesis]." University of Oxford, 2017.

Amnesty International. “Amnesty International Report 2017/2018: The State of the World's Human Rights.” London, 2018.

https://www.amnesty.org/en/documents/pol10/6700/2018/en/.

_. "Female Refugees Face Physical Assault, Exploitation and Sexual Harassment on Their Journey through Europe," 2016. https://www.amnesty.org/en/latest/news/2016/01/femalerefugees-face-physical-assault-exploitation-and-sexual-harassment-on-their-journeythrough-europe/.

Andersson, Ruben. Illegality, Inc.: Clandestine Migration and the Business of Bordering Europe. Oakland, CA: University of California Press, 2014.

Asociación Comunal de Junta Zona 3 Corregimiento de Pacelli. Acuerdos de La Comunidad de Pacelli Para Promover La Paz, La Seguridad, y La Convivencia Ciudadana. Pacelli, Colombia, n.d.

Berry, Marie E. War, Women, and Power: From Violence to Mobilization in Rwanda and Bosnia-Herzegovina. Cambridge: Cambridge University Press, 2018.

Boesten, Jelke, and Polly Wilding. "Transformative Gender Justice: Setting an Agenda." Women's Studies International Forum 51 (2015): 75-80.

Buckley-Zistel, Susanne, and Ulrike Krause. Gender, Violence, Refugees. New York: Berghahn Books, 2017.

Carpenter, Charli. "“Women, Children, and Other Vulnerable Groups': Gender, Strategic Frames and the Protection of Civilians as a Transnational Issue." International Studies Quarterly 49, no. 2 (2005): 295-334.

Cassidy, Kathryn, Nira Yuval-Davis, and Georgie Wemyss. "Intersectional Border(Ing)S.” Political Geography 66 (2018): 139-41.

Castillo-Diaz, Pablo, and Hanny Cueva-Beteta. "The Promise and Limits of Indicators of Women, Peace and Security." In The Oxford Handbook of Gender and Conflict, edited by Fionnuala Ní Aoláin, Naomi Cahn, Dina Francesca Haynes, and Nahla Valji. Oxford: Oxford University Press, 2017.

Centro Nacional de Memoria Histórica. "La Guerra Inscrita En El Cuerpo: Informe Nacional de Violencia Sexual En El Conflicto Armado.” Bogotá, 2017.

Cockburn, Cynthia. "War and Security, Women and Gender: An Overview of the Issues." Gender \& Development 21, no. 3 (2013): 433-52. https://doi.org/10.1080/13552074.2013.846632.

Conciliation Resources. "Borderlands and Peacebuilding: A View from the Margins." Accord Insight, 2018.

CONPEACE. "Ensuring People-Centred Security in Colombia's Borderlands." Oxford, 2019. https://conpeace.ccw.ox.ac.uk/files/conpeacepolicybriefmayenglishpdf.

Duriesmith, David. Masculinity and New War: The Gendered Dynamics of Contemporary Armed Conflict. New York: Routledge, 2017.

Fiddian-Qasmiyeh, Elena. "Gender and Forced Migration." In The Oxford Handbook of Refugee and Forced Migration Studies, edited by Elena Fiddian-Qasmiyeh, Gil Loescher, Katy 
Long, and Nando Sigona. Oxford: Oxford University Press, 2014.

France24. "Desperate Venezuelan Migrants Turn to Colombia Coca Plantations." France24.

February 12, 2019. https://www.france24.com/en/20190212-desperate-venezuelan-

migrants-turn-colombia-coca-plantations.

Freedman, Jane. "Analysing the Gendered Insecurities of Migration." International Feminist Journal of Politics 14, no. 1 (2012): 36-55.

. "Sexual and Gender-Based Violence against Refugee Women: A Hidden Aspect of the

Refugee 'Crisis." Reproductive Health Matters 24, no. 47 (2016): 18-26.

Goldberg, Beverly. "La Mayoría de Muertes de Venezolanas En El País, Entre 2018 y 2019,

Fueron Feminicidios." El Espectador, January 29, 2020.

https://www.elespectador.com/noticias/nacional/la-mayoria-de-muertes-de-venezolanas-enel-pais-entre-2018-y-2019-fueron-feminicidios-articulo-902062.

Hoang, Kimberly Kay. “'She's Not a Low-Class Dirty Girl!': Sex Work in Ho Chi Minh City, Vietnam." Journal of Contemporary Ethnography 40, no. 4 (2011): 367-96.

Human Rights Watch. "La Guerra En El Catatumbo: Abusos de Grupos Armados Contra Civiles Colombianos y Venezolanos En El Noreste de Colombia," 2019. https://www.hrw.org/sites/default/files/report_pdf/colombia0819sp_web_0.pdf.

Humphris, Rachel. "Refugees and the Rashaida: Human Smuggling and Trafficking from Eritrea to Sudan and Egypt," 2013. https://www.unhcr.org/research/working/51407fc69/refugeesrashaida-human-smuggling-trafficking-eritrea-sudan-egypt-rachel.html.

Idler, Annette. Borderland Battles: Violence, Crime, and Governance at the Edges of Colombia's War. Oxford: Oxford University Press, 2019.

_ . "From the Margins of War to the Centre of Peacebuilding: How Gendered Dynamics of Conflict Matter." Journal of Global Security Studies 4, no. 2 (2019): 279-85.

Idler, Annette, Natasha Leite, and Yadaira Orsini. "A Borderland Lens on Hubs of Protracted Conflict." Oxford, 2019.

Jesperson, Sasha. "Conflict and Migration: From Consensual Movement to Exploitation." Stability: International Journal of Security and Development 8, no. 1 (2019): 1-13.

Kamler, Erin. "Women of the Kachin Conflict: Trafficking and Militarized Feminity on the Burma-China Border." Journal of Human Trafficking 1, no. 3 (2015): 209-34.

Korf, Benedikt, and Timothy Raeymaekers. Violence on the Margins: States, Conflict, and Borderlands. New York: Palgrave Macmillan, 2013.

Kreft, Anne-Kathrin. "Responding to Sexual Violence: Women's Mobilization in War." Journal of Peace Research 56, no. 2 (2019): 220-33.

Krystalli, Roxani, Allyson Hawkins, and Kim Wilson. "II Followed the Flood': A Gender Analysis of the Moral and Financial Economies of Forced Migration." Disasters 42, no. 1 (2018): S17-39.

Lewis, Chloe. "Gendering Borderlands: A Research Agenda," 2019.

McGill, Jena. "Survival Sex in Peacekeeping Economies: Re-Reading the Zero Tolerance Approach to Sexual Exploitation and Sexual Abuse in United Nations Peace Support Operations." Journal of International Peacekeeping 18 (2014): 1-44.

Meertens, Donny. "Forced Displacement and Gender Justice in Colombia Between Disproportional Effects of Violence and Historical Injustice." Transitional Justice and Displacement Project (ICTJ and Brookings-LSE), no. July (2012).

Meger, Sara. "The Fetishization of Sexual Violence in International Security." International Studies Quarterly 60, no. 1 (2016): 149-59. 
Menjívar, Cecilia, and Shannon Drysdale Walsh. "Gender, Violence and Migration.” In Handbook on Critical Geographies of Migration, edited by Katharyne Mitchell, Reece Jones, and Jennifer L. Fluri. Cheltenham: Edward Elgar Publishing Inc, 2019.

Morehouse, Barbara, Vera Pavlakovich-Kochi, and Doris Wastl-Walter. "Introduction: Perspectives on Borderlands." In Challenged Borderlands: Transcending Political and Cultural Boundaries, edited by Barbara Morehouse, Vera Pavlakovich-Kochi, and Doris Wastl-Walter. Aldershot: Ashgate, 2004.

Ní Aoláin, Fionnuala, Naomi Cahn, Dina Francesca Haynes, and Nahla Valji. The Oxford Handbook of Gender and Conflict. Oxford: Oxford University Press, 2018.

Nugent, Paul, and Anthony Ijaola Asiwaju. African Boundaries: Barriers, Conduits, and Opportunities. Pinter. London, 1996.

O'Brien, Melanie. Criminalising Peacekeepers: Modernising National Approaches to Sexual Exploitation and Abuse. Basingstoke: Palgrave Macmillan, 2017.

Przeworski, Adam, and Henry Teune. The Logic of Comparative Social Inquiry. New York: John Wiley, 1970.

R4V. "Plataforma de Coordinacíon Para Refugiados y Migrantes de Venezuela," 2020. https://r4v.info/es/situations/platform.

Ratzel, Friedrich. Politische Geographie. Munich: Oldenbourg, 1897.

Sandvik, Kristin Bergtora. "Gendering Violent Pluralism: Women's Political Organising in Latin America." Third World Thematics: A TWQ Journal, June 13, 2018, 1-16. https://doi.org/10.1080/23802014.2018.1477527.

Scorgie-Porter, Lindsay. "Economic Survival and Borderland Rebellion: The Case of the Allied Democractic Forces on the Uganda-Congo Border." The Journal of Middle East and Africa 6, no. 2 (2013): 191-213.

UN Women. "Progress of the World's Women 2019-2020: Families in a Changing World," 2019. https://www.unwomen.org/-

/media/headquarters/attachments/sections/library/publications/2019/progress-of-the-worldswomen-2019-2020-en.pdf?la=en\&vs=3512.

Yuval-Davis, Nira, Georgie Wemyss, and Kathryn Cassidy. Bordering. Cambridge: Polity Press, 2019.

. "Everyday Bordering, Belonging and the Reorientation of British Immigration Legislation." Sociology 52, no. 2 (2018): 228-44.

Zulver, Julia. "Building the City of Women: Creating a Site of Feminist Resistance in a Conflict Zone." Gender, Place, and Culture 24, no. 10 (2017): 1498-1516.

. "High Risk Feminism in Colombia: Women's Mobilisation in Violent Contexts [DPhil Thesis].” University of Oxford, 2018. https://ora.ox.ac.uk/objects/uuid:3fc50c53-d6f5-49c9a3ba-ca68570a78a3.

\footnotetext{
${ }^{1}$ For a discussion of our use of this term, see Idler, Borderland Battles.

${ }^{2}$ R4V, "Plataforma de Coordinacíon Para Refugiados y Migrantes de Venezuela."

${ }^{3}$ CONPEACE, "Ensuring People-Centred Security in Colombia's Borderlands."

${ }^{4}$ Fiddian-Qasmiyeh, "Gender and Forced Migration."

${ }^{5}$ See Chapter 7 of UN Women, "Progress of the World's Women 2019-2020."

${ }^{6}$ Idler, Borderland Battles, 251.

${ }^{7}$ Idler.

${ }^{8}$ CONPEACE, "Ensuring People-Centred Security in Colombia's Borderlands"; Idler, Borderland Battles.
} 
${ }^{9}$ Duriesmith, Masculinity and New War; Ní Aoláin et al., Oxford Handb. Gend. Confl.

${ }^{10}$ Cockburn, "War and Security, Women and Gender: An Overview of the Issues."

${ }^{11}$ Boesten and Wilding, "Transformative Gender Justice: Setting an Agenda," 2.

${ }^{12}$ Meertens, "Forced Displacement and Gender Justice in Colombia"; CMH, "La Guerra Inscrita En El Cuerpo";

Zulver, "Building the City of Women"; Zulver, "High Risk Feminism in Colombia"; Kreft, "Responding to Sexual

Violence"; Idler, "From the Margins of War to the Centre of Peacebuilding:"

${ }^{13}$ Fiddian-Qasmiyeh, "Gender and Forced Migration"; Buckley-Zistel and Krause, Gender, Violence, Refugees.

${ }^{14}$ Buckley-Zistel and Krause.

${ }^{15}$ Freedman, "SGBV against Refugee Women." See also Amnesty International, "Female Refugees Face Physical Assault, Exploitation and Sexual Harassment on Their Journey through Europe.",

${ }^{16}$ Freedman, "Analysing the Gendered Insecurities of Migration." See also Achtnicht, "Mobility in Crisis: Sub-

Saharan Migrants' Journeys through Libya and Malta [Doctoral Thesis]."

${ }^{17}$ Menjívar and Drysdale Walsh, "Gender, Violence and Migration."

${ }^{18}$ Korf and Raeymaekers, Violence on the Margins: States, Conflict, and Borderlands; Scorgie-Porter, "Economic Survival and Borderland Rebellion."

${ }^{19}$ Conciliation Resources, "Borderlands and Peacebuilding"; Lewis, "Gendering Borderlands."

${ }^{20}$ For critiques on this approach, see Carpenter, "'Women, Children, and Other Vulnerable Groups'."

${ }^{21}$ Meger, "The Fetishization of Sexual Violence in International Security."

${ }^{22}$ Krystalli, Hawkins, and Wilson, "II Followed the Flood'."

${ }^{23}$ Sandvik, "Gendering Violent Pluralism"; Kreft, "Responding to Sexual Violence."

${ }^{24}$ Berry, War, Women, and Power.

${ }^{25}$ Deported Colombians who had previously lived in Venezuela. Many of them had fled violence in Colombia during the 1990s and 2000s. While some chose to come back to Colombia as part of the humanitarian crisis, some were deported in 2015 under a policy led by the Chávez government.

${ }^{26}$ Przeworski and Teune, The Logic of Comparative Social Inquiry.

${ }^{27}$ Which Idler differentiates as "enmity, rivalry, and friendship" clusters.

${ }^{28}$ These groups range from small-scale neighbourhood organisations to national-level advocacy organisations.

${ }^{29}$ Yuval-Davis, Wemyss, and Cassidy, "Everyday Bordering, Belonging and the Reorientation of British

Immigration Legislation"; Yuval-Davis, Wemyss, and Cassidy, Bordering.

${ }^{30}$ See for example Andersson, Illegality, Inc.: Clandestine Migration and the Business of Bordering Europe.

${ }^{31}$ Cassidy, Yuval-Davis, and Wemyss, "Intersectional Border(ing)s."

${ }^{32}$ Idler, Borderland Battles.

${ }^{33}$ Idler. See especially Chapter 7 for a detailed discussion of the border effect.

${ }^{34}$ Nugent and Asiwaju, African Boundaries: Barriers, Conduits, and Opportunities.

${ }^{35}$ Ratzel, Politische Geographie; Morehouse, Pavlakovich-Kochi, and Wastl-Walter, "Introduction: Perspectives on Borderlands."

${ }^{36}$ Korf and Raeymaekers, Violence on the Margins: States, Conflict, and Borderlands.

${ }^{37}$ Idler, Borderland Battles; Idler, Leite, and Orsini, "A Borderland Lens on Hubs of Protracted Conflict."

${ }^{38}$ Amnesty International, “Amnesty International Report 2017/2018.”

${ }^{39}$ For a discussion of survival sex in vulnerable contexts, see O'Brien, Criminalising Peacekeepers, 11-12. See also McGill, "Survival Sex in Peacekeeping Economies:."

${ }^{40}$ See map in Idler, 77.

${ }^{41}$ Kamler, "Women of the Kachin Conflict: Trafficking and Militarized Feminity on the Burma-China Border"; Humphris, "Refugees and the Rashaida: Human Smuggling and Trafficking from Eritrea to Sudan and Egypt."

${ }^{42}$ We use this word intentionally: while the term may carry negative connotations for some, it is the word that most interviewees used, including prostitutes themselves. We choose to differentiate this from "sex work", given the unclear boundary between sex work and survival sex in this case. For a similar discussion on how sex workers refer to themselves, see Hoang, “'She's Not a Low-Class Dirty Girl!': Sex Work in Ho Chi Minh City, Vietnam."

${ }^{43}$ Buckley-Zistel and Krause, Gender, Violence, Refugees.

${ }^{44}$ Idler, Borderland Battles.

${ }^{45}$ France24, "Desperate Venezuelan Migrants Turn to Colombia Coca Plantations."

${ }^{46}$ See, for example, Goldberg, "La Mayoría de Muertes de Venezolanas En El País, Entre 2018 y 2019, Fueron Feminicidios." 
${ }^{47}$ Human Rights Watch, "La Guerra En El Catatumbo."

${ }^{48}$ For a nuanced typology of trafficking dynamics during conflict, see Jesperson, "Conflict and Migration."

${ }^{49}$ Copy on file with the authors.

${ }^{50}$ Idler, Borderland Battles.

${ }^{51}$ In Castillo-Diaz and Cueva-Beteta, "The Promise and Limits of Indicators of Women, Peace and Security." 